\title{
UJI KEKUATAN MUTU BETON TERHADAP PENGARUH CUACA PADA VARIASI WAKTU TERTENTU DALAM PERLAKUAN PADA SAMPEL KUBUS SISI 15 CM
}

\author{
Aminullah \\ Dosen Universitas Nahdlatul Ulama Kalimantan Selatan \\ E-mail : aminullah.ak@gmail.com/HP. +6281351960007
}

\begin{abstract}
Abstrak
Pembangunan gedung konstruksi beton kadang terjadi permasalahan setelah rangka konstruksi sudah dibangun sebelum penyelesaiannya masalah ini bisa berupa perizinan, sengketa lahan, terjadi penyimpangan dalam pelaksanaannya sehingga diputuskan untuk dihentikan, kekurangan modal atau terjadi krisis moneter nasional. Terbengkalainya konstruksi bangunan yang terbuat dari beton bertulang tentu mengalami pengaruh cuaca panas dan hujan dalam kurun waktu tertentu, penelitian ini dilakukan menguji sampel material beton yang berada di perlindungan panas dan hujan dan material beton yang mengalami pengaruh cuaca panas dan hujan dalam beberapa waktu dalam hal ini diambil waktu 180 hari dan 360 hari, dalam penelitian ini ada 3 buah sampel yang antara lain terlindung dengan pengaruh cuaca 180 hari dan 360 hari, proses penelitian mengacu kepada petunjuk dasar penelitian bahan dengan material pembentuk bahan beton yang sama, proses pengolahan yang sama namun perlakuan terhadap sampel yang berbeda. Hasil penelitian menunjukkan bahwa beton yang mengalami pengaruh cuaca alam seperti panas dan hujan atau tanpa perlindungan mengalami kekuatan tekan yang berbanding terbalik dengan waktu pengaruh cuaca alam dalam arti lebih lama konstruksi beton terbengkalai maka lebih rendah kekuatan mutu betonnya.

Kata Kunci: Material Beton, Terlindung, Pengaruh Cuaca, Kekuatan Tekan Berbanding Terbalik.
\end{abstract}

\begin{abstract}
The construction of concrete construction buildings sometimes occurs when problems occur after the construction framework has been built before the resolution of these problems can be in the form of permits, land disputes, irregularities in implementation so that it is decided to be stopped, lack of capital or a national monetary crisis occurs. The neglected construction of buildings made of reinforced concrete will certainly experience the effects of hot and rainy weather within a certain period of time, this study was conducted to test samples of concrete materials that were in heat and rain protection and concrete materials that experienced the effects of hot and rainy weather for some time in this case. 180 days and 360 days were taken, in this study there were 3 samples which included protection from the effects of 180 days and 360 days of weather, the research process refers to the basic instructions for material research with the same concrete forming material, the same processing but treatment against different samples. The results showed that concrete that experienced the effects of natural weather such as heat and rain or without protection experienced
\end{abstract}


compressive strength which was inversely proportional to the time of the effect of natural weather in the sense that the longer the concrete construction was neglected, the lower the strength of the concrete quality.

Keywords: Concrete Material, Shielded, Weather Effect, Compressive Strength is inversely proportional.

\section{Latar Belakang}

\section{PENDAHULUAN}

Seperti kita ketahui bersama, setiap adanya pembangunan khususnya pembangunan fisik yang berkaitan dengan ilmu sipil, selalu saja disertai oleh beragam persoalan. Dari proses perencanaan sampai pelaksanaan, selalu tidak lepas dari masalah, baik masalah biaya yang berkenaan dengan keadaan krisis ekonomi sekarang ini, kurangnya bahan atau material yang tersedia, maupun sampai kepada masalah yang berkaitan dengan hukum dan perizinan yang pada akhirnya itu semua akan menghambat kelancaran pelaksanaan suatu proyek pembangunan. Apalagi kalau itu proyek swasta/masyarakat. Maka untuk mengetahui hal tersebut sangat dibutuhkan suatu pengetahuan atau penelitian untuk dapat memperkirakan pengaruh cuaca terhadap kuat tekan beton, sehingga diharapkan nantinya hal ini bisa menjadi salah satu faktor/bahan pertimbangan dan pemikiran dalam merencanakan pelaksanaan suatu proyek.

\section{Perumusan Masalah}

1. Berapa hasil kekuatan beton pada beberapa sampel; terlindung selama 180 hari, tidak terlindung selama 180 hari dan tidak terlindung selama 360 hari?

2. Berapakah penurunan tegangan dari sampel; terlindung selama 180 hari, tidak terlindung selama 180 hari dan tidak terlindung selama 360 hari?

3. Berapakah perbandingan penurunan tegangan pada poin 2 diatas?

\section{Tujuan Penelitian}

1. Untuk mengetahui hasil kekuatan beton pada beberapa sampel; terlindung selama 180 hari, tidak terlindung selama 180 hari dan tidak terlindung selama 360 hari.

2. Untuk mengetahui penurunan tegangan dari sampel; terlindung selama 180 hari, tidak terlindung selama 180 hari dan tidak terlindung selama 360 hari.

3. Untuk mengetahui perbandingan penurunan tegangan pada poin 2 diatas.

\section{TINJAUAN PUSTAKA}

Beton adalah campuran antara semen Portland atau semen hidrolis, agregat kasar, agregat halus dan air membentuk masa padat, sifat-sifat beton antara lain susut dan memuai, setiap pengeringan dan pembasahan menyebabkan muai dan susut (Menurut Masky dan Bungery, 2004) sifat lain yaitu keawetan, keawetan beton terutama tergantung pada tingkat perlindungan yang diberikan kepada konstruksi beton itu dan tulangannya, kekuatan beton karakteristik menurut PBI 1971 adalah kekuatan tekan dimana dari sejumlah besar hasil-hasil pemeriksaan kemungkinan adanya kekuatan tekan yang kurang atau terbatas sampai 5\% saja. Beton adalah suatu bahan konstruksi yang mempunyai sifat kekuatan tekan yang khas, yaitu apabila diperiksa dengan sejumlah besar benda-benda uji nilainya akan menyebar sekitar suatu nilai rata-rata tertentu. 
Beton dengan mutu K-225 adalah beton yang mempunyai tekanan karakteristik 225 , maksudnya beton yang mampu menahan tekanan sebesar $225 \mathrm{~kg}$ dalam luas sebesar $1 \mathrm{~cm} 2$ dalam umur 28 hari.

\section{Bahan-Bahan Campuran Beton}

Agregat

Menurut PBI 1971, agregat butiran-butiran mineral yang dicampurkan dengan semen Portland dan air menghasilkan beton. Sekitar $\pm 75 \%$ agregat menempati dari isi total beton, maka agregat sangat berpengaruh terhadap perilaku beton yang sudah mengeras. Sifat dari agregat bukan hanya mempengaruhi ketahanan. Agregat terbagi atas 2 jenis, yaitu:

1. Agregat Halus (Pasir) Agregat halus untuk beton adalah agregat berupa pasir alam sebagai hasil desintegrasi alami dari batuan-batuan atau berupa pasir buatan yang dihasilkan oleh alat-alat pemecah batu dan mempunyai ukuran butiran sebesar $5 \mathrm{~mm}$ (SKSNI S-04-1989-F).

Menurut SN1 1989 dalam spesifikasi, agregat halus harus memenuhi persyaratan dibawah ini antara lain sebagai berikut:

a. Butiran agregat halus harus terdiri dari butir-butir yang tajam dan Keras.

b. Butir-butir agregat halus harus bersifat kekal, artinya tidak pecah atau hancur oleh pengaruh-pengaruh cuaca.

c. Sifat kekal, apabila di uji dengan larutan jenuh garam sulfat sebagai berikut:

1) Jika dipakai Natrium Sulfat, bagian yang hancur maksimum $12 \%$.

2) Jika dipakai Magnesium Sulfat, bagian yang hancur, maksimum $10 \%$.

3) Tidak boleh mengandung lumpur lebih dari 5\% (ditentukan terhadap berat kering). Lumpur adalah bagian-bagian yang dapat melalui ayakan 0,060 mm. Apabila kadar lumpur melampaui 5\% maka agregat harus dicuci.

4) Tidak boleh mengandung bahan-bahan organis terlalu banyak yang harus dibuktikan dengan percobaan warna dari Abrams - Herder.

5) Susunan besar butir agregat halus mempunyai modulus kehalusan antara 1,5 - 3,8 dan harus terdiri dan butir-butir yang beraneka ragam besarnya. Apabila diayak dengan susunan ayakan yang ditentukan, harus masuk salah satu dalam daerah susunan butir menurut zone: 1,2,3, atau 4 (SKBI / BS.882).

\section{METODE PENELITIAN}

Penelitian menggunakan test pada pengujian di laboratorium. Langkah kerja atau kegiatan yang dilakukan dalam penelitian:

1. Studi literatur untuk mengawali proses penelitian sebagai pendukung teori, yaitu:

- Studi untuk bahan material beton seperti pasir, kerikil, semen Portland serta air, yang mana untuk penelitian ini pasir yang digunakan adalah pasir Rantau, untuk kerikil yang digunakan adalah kerikil Kandangan, sedang bahan pengikat yang digunakan adalah semen Tiga Roda serta air yang digunakan adalah air PDAM. 
- Adanya pengujian bahan-bahan material tersebut di laboratorium untuk masing-masing bahan.

- Analisa hasil pengujian bahan serta pembuatan laporan hasil pengujian.

2. Menyiapkan material beton untuk pembuatan benda uji laboratorium.

3. Mix design dan pembuatan beton segar untuk sample benda uji dalam bentuk kubus. Jumlah sample benda uji dibuat sebanyak 60 buah sample, yang mana diperlukan dalam 20 buah sample untuk uji beton normal sebagai perbandingan kuat tekan, 20 buah sample untuk uji kuat tekan beton yang dibiarkan di alam terbuka tidak dipelihara selama 3 bulan dan 20 buah lagi untuk uji kuat tekan beton yang dibiarkan di alam terbuka tidak dipelihara selama 6 bulan. Semua sample beton dipelihara/dirawat di laboratorium dengan umur (selama) 28 hari, baru setelah itu dibedakan pemberian perlakuan menurut keperluan masing-masing (terbengkalai terkena pengaruh cuaca panas dan hujan sebanyak 40 buah dan 20 buah untuk yang tidak terkena pengaruh cuaca panas dan hujan secara langsung).

4. Uji kubus/pemeriksaan kuat tekan beton. Sample beton yang terkena pengaruh cuaca panas dan hujan secara langsung setelah mencapai masa waktu 6 bulan di uji kuat tekannya. Demikian pula untuk sampel beton yang normal yang terkena panas dan hujan secara langsung diuji kuat tekannya pada masa waktu 6 bulan. Sedangkan yang 20 sampel sisa terus ditelantarkan sampai masa 12 bulan baru setelah itu diuji kuat tekannya.

5. Menganalisa data dari hasil pengujian sampel beton dengan metode statistik.

6. Langkah terakhir adalah menarik kesimpulan dari hasil analisa dan perhitungan.

\section{HASIL DAN PEMBAHASAN}

\section{Berat Jenis Semen Portland}

Tujuan pemeriksaan ini untuk menentukan berat jenis semen Portland. Dari hasil penelitian diperoleh berat jenis semen Portland, $\mathrm{Bj}=3,152 \mathrm{gr} / \mathrm{cm}^{3}$. bila berat jenis semen Portland sekitar $3,15 \mathrm{gr} / \mathrm{cm}^{3}-3,17 \mathrm{gr} / \mathrm{cm}^{3}$.

\section{Pemeriksaan Konsistensi Normal dari Semen Portland}

Penelitian ini bertujuan untuk menentukan konsistensi normal dari semen hidrolis untuk keperluan penentuan waktu pengikat dari semen (Rivani, 1995). Hasil penelitian dan perhitungan:

- Konsistensi normal tercapai jika jarum $\mathrm{C}$ menembus batas $(10 \pm 1 \mathrm{~mm})$ dibawah permukaan dalam waktu 30 detik setelah dilepaskan.

- Pada pengujian penurunan terjadi sebesar $9 \mathrm{~mm}$ jadi telah memenuhi syarat.

- Kondisi normal tercapai pada perbandingan semen 500 gram dan air 110 cc.

\section{Penentuan Waktu Pengikatan dari Semen Hidrolis}

Penelitian ini untuk menentukan waktu-waktu pengikatan permulaan semen hidrolis. Dari hasil penelitian yang dilakukan didapat hasil sebagai berikut:

- Konsistensi normal : $22 \%$

- Suhu kamar : $28^{\circ} \mathrm{C}$

- Waktu pengikatan permulaan/awal : 44,25 menit

- Waktu pengikatan akhir : 105 menit 


\section{Berat Isi Agregat Halus dan Kasar}

Tujuan pemeriksaan ini untuk menentukan berat isi agregat halus, kasar atau campuran. Berat isi adalah perbandingan berat dan isi. Dari hasil penelitian dan perhitungan didapat berat agregat halus (pasir) dan agregat kasar (kerikil) sebagai berikut:

- Agregat Halus (pasir Rantau)

- Kondisi lepas : $1,4219 \mathrm{gr} / \mathrm{cm}^{3}$

- Kondisi goyangan : 1,4800 gr/ $/ \mathrm{cm}^{3}$

- Kondisi tusukan : $1,5409 \mathrm{gr} / \mathrm{cm}^{3}$
- Agregat Kasar (kerikil Kandangan)

- Kondisi lepas $\quad: 1,8021 \mathrm{gr} / \mathrm{cm}^{3}$

- Kondisi goyangan : $1,8209 \mathrm{gr} / \mathrm{cm}^{3}$

- Kondisi tusukan : $1,8557 \mathrm{gr} / \mathrm{cm}^{3}$

\section{Analisa Saringan Agregat Halus dan Kasar}

Pemeriksaan ini untuk menentukan pembagian butir (gradasi) agregat halus dan kasar dengan menggunakan saringan (Rivani, 1995). Hasil dari percobaan didapatkan:

- Agregat halus (pasir Rantau) termasuk dalam kategori zona I, dengan demikian pasir tersebut termasuk bergradasi sangat baik.

- Agregat kasar (kerikil Kandangan) termasuk dalam kategori zona I, dengan demikian kerikil tersebut termasuk bergradasi sangat baik.

\section{Pemeriksaan Organik Dalam Agregat Halus}

Pemeriksaan ini untuk menentukan adanya bahan organik yang terkandung di dalam agregat halus untuk digunakan dalam adukan beton. Pada hasil percobaan pemeriksaan organik agregat halus (pasir Rantau) termasuk klasifikasi dalam No.2.

7. Analisa Specific Gravity dan Absorption Agregat Kasar

Tujuan analisa ini untuk menentukan bulk dan apparent specific gravities dan absorption dan agregat kasar menurut ASTM C-127 guna menentukan volume agregat-agregat dalam beton. Dari hasil percobaan agregat kasar dapat dinyatakan bahwa:

- Apparent specific gravity : : 2,309 gr

- Bulk specific gravity : $2,519 \mathrm{gr}$

- Bulk specific gravity SSD Basic : $2,595 \mathrm{gr}$

- Prosentase water absorption : 4,763 gr

8. Analisa Specific Gravity dan Absorption Agregat Halus

Tujuan dari percobaan ini untuk menentukan bulk dan apparent specific gravity dan absorption dari agregat halus menurut ASTM C-128. Dari hasil percobaan agregat halus dapat dinyatakan bahwa:

- Apparent specific gravity $\quad: 2,534 \mathrm{gr}$

- Bulk specific gravity on dry basic : 2,300 gr

- Bulk specific gravity SSD Basic : 2,392 gr

- Prosentase water absorption : 4,015 gr

9. Pemeriksaan Kasar Air Agregat Halus dan Kasar

Pemeriksaan ini untuk menentukan kadar air agregat. Dari hasil percobaan dan perhitungan didapat kadar air:

- Agregat halus : $4,142 \%$

- Agregat kasar : $1,975 \%$

10. Pemeriksaan Kadar Lumpur Agregat Halus Dan Agregat Kasar Lewat Saringan No.200 
Tujuan dari percobaan untuk menentukan jumlah bahan yang terdapat dalam agregat lewat saringan No.200 dengan cara pencucian. Berdasarkan hasil penelitian didapat kadar lumpur untuk agregat halus (pasir) $=2,5 \%$ dan untuk agregat kasar (kerikil) $=0,91 \%$. Berdasarkan SNI 1989 dalam spesifikasi, yaitu untuk agregat halus tidak boleh mengandung lumpur lebih dari 5\% dan untuk agregat kasar tidak boleh mengandung lumpur lebih dari $1 \%$.

\section{Pemeriksaan Abrasi}

Pemeriksaan ini untuk dapat menentukan ketahanan agregat kasar dari keausan dengan mempergunakan mesin Los Angeles. Dari hasil percobaan didapat keausan sebesar $23,1 \%$ maka agregat kasar tersebut (kerikil Kandangan) tahan dari daya tahan geser $(\mathrm{d}=23,1 \%<\mathrm{d}=50 \%$ yang disyaratkan).

\section{Perencanaan Beton k-225 (mix design)}

Dalam perencanaan ini digunakan konsepsi perencanaan campuran beton berdasarkan metode DOE atau Department of Environmental (SK-SNI-T-151990-03). Cara ini merupakan cara yang paling sering digunakan di Indonesia.

Data perencanaan campuran beton yang dibuat:

- Volume pengecoran kurang dari $1000 \mathrm{~m}$.

- Kondisi beton tidak terlindung dari hujan dan terik matahari langsung.

- At tekan karakteristik $225 \mathrm{~kg} / \mathrm{cm}^{2}$.

- Semen yang dipakai semen Portland tipe 1 (tiga roda).

- Agregat halus yang dipakai pasir Rantau.

- Agregat kasar yang dipakai kerikil Kandangan.

- Air PDAM

\section{Deviasi Standard}

Deviasi standar diketahui dari besarnya jumlah (volume) pengecoran yang akan dibuat. Hal ini dapat dilihat pada tabel dibawah ini:

Tabel Mutu Pelaksanaan Diukur Dengan Standard Deviasi

\begin{tabular}{|l|c|c|c|c|}
\hline \multicolumn{2}{|c|}{ Isi Pekerjaan } & \multicolumn{3}{c|}{$\begin{array}{c}\text { Standard Deviasi (S) } \\
\mathbf{k g} / \mathbf{c m}^{\mathbf{2}}\end{array}$} \\
\hline \multicolumn{1}{|c|}{ Sebutan } & $\begin{array}{c}\text { Jumlah Beton } \\
\left(\mathbf{m}^{\mathbf{2}}\right)\end{array}$ & Baik Sekali & Baik & Dapat Diterima \\
\hline Kecil & $<1000$ & $45<\mathrm{S} \leq 55$ & $55<\mathrm{S} \leq 65$ & $65<\mathrm{S} \leq 85$ \\
Sedang & $1000-3000$ & $35<\mathrm{S} \leq 45$ & $45<\mathrm{S} \leq 55$ & $55<\mathrm{S} \leq 75$ \\
Besar & $>3000$ & $25<\mathrm{S} \leq 35$ & $35<\mathrm{S} \leq 45$ & $45<\mathrm{S} \leq 65$ \\
\hline
\end{tabular}

Nilai deviasi standard yang dihitung dari data hasil uji tersebut dengan faktor pengali dari tabel.

Tabel Faktor Pengali Untuk Deviasi Standar Bila Data Hasil Uji Yang Tersedia Kurang Dari 30

\begin{tabular}{|c|c|}
\hline Jumlah Pengujian & Faktor Pengali Deviasi Standard \\
\hline Kurang dari 15 & Lihat ayat 3.1.1 butir 1 sub butir 5 \\
15 & 1,16 \\
20 & 1,08 \\
25 & 1,03 \\
30 atau lebih & 1,00 \\
\hline
\end{tabular}


JURNAL KACAPURI

JURNAL KEILMUAN TEKNIK SIPIL

Volume 3 Nomor 2 Edisi Desember 2020

Bahan

Tabel Jenis Bahan Yang Dipakai

\begin{tabular}{|c|c|c|}
\hline Baik Sekali & Baik & Dapat Diterima \\
\hline $\begin{array}{c}\text { Semen Tiga Roda } \\
\text { Tipe I }\end{array}$ & Agregat Kasar Alami & Agregat Halus Alami \\
Kerikil Kandangan & Pasir Rantau \\
\hline
\end{tabular}

Kuat Tekan Rata-Rata Rencana (orang ditargetkan)

Rumus : $f c r=f c+\mathrm{M}(\mathrm{SK} \mathrm{SNI})$

Slump Beton

$f c r=225+106,3=331,3 \mathrm{~kg} / \mathrm{cm}^{2}$

Untuk nilai slump beton sebagai pekerjaan beton didapat:

Tabel Nilai Slump Untuk Pekerjaan Beton Rencana

\begin{tabular}{|l|c|c|}
\hline \multirow{2}{*}{ Uraian } & \multicolumn{2}{|c|}{ Slump (cm) } \\
\cline { 2 - 3 } & Maksimum & Minimum \\
\hline Pelat, balok, kolom dan dinding & 15,0 & 7,5 \\
\hline
\end{tabular}

Tabel Daftar Isian (Formulir Rancangan Campuran Beton

\begin{tabular}{|c|c|c|c|c|c|c|}
\hline No. & Uraian & \multicolumn{3}{|c|}{$\begin{array}{l}\text { Tabel/Grafik/ } \\
\text { Perhitungan }\end{array}$} & \multicolumn{2}{|r|}{ Nilai } \\
\hline 1. & Tegangan Karakteristik & \multicolumn{3}{|c|}{ Ditetapkan } & \multicolumn{2}{|c|}{$\begin{array}{l}22,5 \mathrm{n} / \mathrm{mm}^{2} \text { padi } 28 \text { hari Bagian } \\
\text { cacat } 5 \%\end{array}$} \\
\hline 2. & Standar T Deviasi & \multicolumn{3}{|c|}{ Ayat 3.3.1 (tabel 1) } & \multicolumn{2}{|c|}{$\begin{array}{l}6 \mathrm{n} / \mathrm{mm}^{2} \text { atau tanpa data } \\
6 \times 1,08=6,48 \mathrm{n} / \mathrm{mm}^{2} 1,64 \times\end{array}$} \\
\hline 3. & Margin (Nilai Tambah) Rencana & \multicolumn{3}{|c|}{$(\mathrm{K}=1,64)$} & \multicolumn{2}{|c|}{$6,48=10,63 \mathrm{n} / \mathrm{mm}^{2}$} \\
\hline 4. & Tegangan Rata-Rata & \multicolumn{3}{|c|}{ Ayat 3.3.2 } & \multicolumn{2}{|c|}{$22.5+10,63=33,13 \mathrm{n} / \mathrm{mm}^{2}$} \\
\hline 5. & Jenis Semen & \multicolumn{3}{|c|}{ Ditetapkan } & \multicolumn{2}{|c|}{$\begin{array}{l}\text { Semen Portland Type I (Tiga } \\
\text { Roda) }\end{array}$} \\
\hline 6. & Jenis Agregat Kasar & \multicolumn{3}{|c|}{ Ditetapkan } & \multicolumn{2}{|c|}{ Kerikil Kandangan } \\
\hline 7. & Jenis Agregat Halus & \multicolumn{3}{|c|}{ Ditetapkan } & \multicolumn{2}{|c|}{ Pasir Rantau } \\
\hline 8. & Air Semen Maksimum & Tabel 3 & \multicolumn{2}{|c|}{ Tabel 2, grafik 1 dan grafik 2} & \multicolumn{2}{|l|}{0,60} \\
\hline 9. & Slump & \multicolumn{3}{|c|}{ Ditetapkan, ayat 3.3.3. } & \multicolumn{2}{|c|}{ Slump $75-150 \mathrm{~mm}$} \\
\hline 10. & Ukuran Agregat Maksimum & \multicolumn{3}{|c|}{ Ditetapkan ayat 3.3.4. } & \multicolumn{2}{|c|}{$40 \mathrm{~mm}$} \\
\hline 11. & Kadar Air bebas & \multicolumn{3}{|c|}{ Tabel 6, ayat 3.3.5. } & \multicolumn{2}{|c|}{$175 \mathrm{~kg} / \mathrm{m}^{3}$} \\
\hline 12. & Jumlah Semen & \multicolumn{3}{|c|}{$11: 8$ atau 7} & \multicolumn{2}{|c|}{$175: 0,55=318,18 \mathrm{~kg} / \mathrm{m}^{3} 291,67$} \\
\hline 13. & Jumlah Semen Maksimum & \multicolumn{3}{|c|}{ Ditetapkan $(175: 0,6)$} & \multicolumn{2}{|l|}{$\mathrm{kg} / \mathrm{m}^{3}$} \\
\hline 14. & $\begin{array}{l}\text { Jumlah Semen Minimum (Dipakai } \\
\text { Bila }>12 \text { dan Hitung } 15\end{array}$ & \multicolumn{3}{|c|}{ Ditetapkan, tabel 3} & \multicolumn{2}{|c|}{$325,00 \mathrm{~kg} / \mathrm{m}^{3}$} \\
\hline 15. & Faktor Air Semen Yang Disesuaikan & \multicolumn{3}{|c|}{$175: 325$} & \multicolumn{2}{|l|}{0,54} \\
\hline 16. & $\begin{array}{l}\text { Susunan Besar Butiran Agregat } \\
\text { Halus }\end{array}$ & Grafik & $/ \mathrm{d} 12$ & & Daerah & dasi susunan bulir 1 \\
\hline 17. & Persen Agregat halus & Grafik & s/d 12 & & $46,5 \%$ & sen) \\
\hline 18. & Berat Jenis Agregat Gabungan (SSD) & $\begin{array}{l}(0,465 \\
2,51)\end{array}$ & $392+0,5$ & & $2,50 \mathrm{dik}$ & dianggap \\
\hline 19. & Berat Jenis Beton & Grafik & & & $2320 \mathrm{~kg}$ & \\
\hline 20. & Kadar Agregat Gabungan & $19-($ & $-11)$ & & $2320-5$ & $=1820 \mathrm{~kg} / \mathrm{m}^{3}$ \\
\hline 21. & $\begin{array}{l}\text { Kadar Agregat Halus } \\
\text { Kadar Agregat Kasar }\end{array}$ & $\begin{array}{l}17 \times 2 \\
20-2\end{array}$ & & & $\begin{array}{l}0,465 \times \\
-846,3\end{array}$ & $\begin{array}{l}20=846,3 \mathrm{~kg} / \mathrm{m}^{3} 1820 \\
73,7 \mathrm{~kg} / \mathrm{m}^{3}\end{array}$ \\
\hline $\begin{array}{l}\text { Prop } \\
-\quad T \\
-\quad T\end{array}$ & $\begin{array}{l}\text { orsi Campuran } \\
\text { iap } \mathrm{m}^{3} \text { dengan ketel } 5 \mathrm{~kg} \\
\text { iap campuran uji } 0,1 \mathrm{~m}^{3}\end{array}$ & $\begin{array}{c}\text { Semen } \\
(\mathbf{k g}) \\
325 \\
32,5\end{array}$ & $\begin{array}{c}\begin{array}{c}\text { Air } \\
\text { (kg/liter) }\end{array} \\
175 \\
17,5\end{array}$ & Agr & $\begin{array}{l}\text { al Halus } \\
\text { (g) } \\
6,3 \\
, 63\end{array}$ & $\begin{array}{c}\text { Agregat Kasar (kg) } \\
973,70 \\
97,37\end{array}$ \\
\hline
\end{tabular}


JURNAL KACAPURI

JURNAL KEILMUAN TEKNIK SIPIL

Volume 3 Nomor 2 Edisi Desember 2020

Tabel Hasil Pemeriksaan Kuat Tekan Beton Variasi Sampel Tidak Mendapat Pengaruh Cuaca (Panas/Hujan) Secara Langsung

\begin{tabular}{|c|c|c|c|c|c|c|c|c|c|c|c|c|c|c|}
\hline \multirow[b]{2}{*}{ No. } & \multirow{2}{*}{$\begin{array}{c}\text { Umur } \\
\text { Hari }\end{array}$} & \multirow[b]{2}{*}{$\begin{array}{c}\text { Berat } \\
\text { (gr) }\end{array}$} & \multirow{2}{*}{$\begin{array}{c}\text { Benda } \\
\text { UJi }\end{array}$} & \multirow[b]{2}{*}{ Konversi } & \multirow{2}{*}{$\begin{array}{c}\text { Slump } \\
(\mathbf{c m})\end{array}$} & \multirow{2}{*}{$\begin{array}{c}\text { Ukuran } \\
\left(\mathrm{cm}^{2}\right)\end{array}$} & \multirow{2}{*}{\begin{tabular}{|c|} 
Beban \\
Max \\
$(\mathbf{k g})$ \\
\end{tabular}} & \multicolumn{2}{|c|}{ Tekanan $\left(\mathbf{k g} / \mathbf{c m}^{2}\right)$} & \multirow{2}{*}{$\begin{array}{l}\text { Rata- } \\
\text { rata } \\
\text { obm }\end{array}$} & \multirow{2}{*}{$\begin{array}{l}\Sigma \mathbf{\Sigma b}- \\
\sigma \mathbf{b m}\end{array}$} & \multirow{2}{*}{$\begin{array}{c}(\sigma \mathbf{b}- \\
\sigma \mathbf{b m})^{2}\end{array}$} & \multirow{2}{*}{$\begin{array}{l}\text { Standar } \\
\text { Deviasi } \\
\text { (S) }\end{array}$} & \multirow{2}{*}{$\begin{array}{c}\sigma b k \\
\left(\mathbf{k g} / \mathrm{cm}^{2}\right)\end{array}$} \\
\hline & & & & & & & & Hari & $\begin{array}{c}90 \text { hari } \\
\sigma b\end{array}$ & & & & & \\
\hline 1 & 2 & 3 & 4 & 5 & 6 & 7 & 8 & 9 & 10 & 11 & 12 & 13 & 14 & 15 \\
\hline 1 & \multirow{20}{*}{180} & 8090 & \multirow{20}{*}{ Kubus } & \multirow{20}{*}{1,20} & \multirow{20}{*}{8} & \multirow{20}{*}{225} & 96220 & 427,64 & 356,237 & \multirow{20}{*}{370,85} & $-14,48$ & 209.67 & \multirow{20}{*}{11,00} & \multirow{20}{*}{352,81} \\
\hline 2 & & 8295 & & & & & 100400 & 446,22 & 371,85 & & 1,00 & 1,00 & & \\
\hline 3 & & 8156 & & & & & 102900 & 457233 & 381,11 & & 10,25 & 105,27 & & \\
\hline 4 & & 8245 & & & & & 102450 & 455,33 & 379,44 & & 8,59 & 73,79 & & \\
\hline 5 & & 8209 & & & & & 100100 & 444,89 & 370,74 & & $-0,11$ & 0,01 & & \\
\hline 6 & & 8120 & & & & & 103800 & 461,33 & 384,44 & & 13,59 & 184,69 & & \\
\hline 7 & & 8213 & & & & & 102400 & 455,11 & 379,25 & & 8,41 & 70,73 & & \\
\hline 9 & & 8240 & & & & & 104450 & 464,22 & 386,55 & & 16,00 & 255,00 & & \\
\hline 9 & & 8053 & & & & & 99450 & 442,00 & 368,233 & & $-2,52$ & 6,35 & & \\
\hline 10 & & 8135 & & & & & 95550 & 424,67 & 353,89 & & $-16,96$ & 287,64 & & \\
\hline 11 & & 8089 & & & & & 100400 & 446.22 & 371,85 & & 1,00 & 1,00 & & \\
\hline 12 & & 8100 & & & & & 101600 & 451,55 & 376,230 & & 5,45 & 29,70 & & \\
\hline 13 & & 8008 & & & & & 96550 & 429,11 & 357,59 & & -13226 & 175,83 & & \\
\hline 14 & & 8285 & & & & & 93700 & 416,44 & 347,04 & & $-23,81$ & 566,92 & & \\
\hline 15 & & 8271 & & & & & 96550 & 429,11 & 357,59 & & $-13,26$ & 175,83 & & \\
\hline 16 & & 8145 & & & & & 100850 & $44 S .22$ & 373,52 & & 2,67 & 7,13 & & \\
\hline 17 & & 8200 & & & & & 101100 & 449233 & 374,44 & & 3,59 & 12,89 & & \\
\hline IS & & 8200 & & & & & 101700 & 452,00 & 376,67 & & 5,82 & 33,87 & & \\
\hline 19 & & 8247 & & & & & $102 \mathrm{~S} 00$ & $456, \mathrm{~S} 9$ & 380,74 & & 9,89 & 97,81 & & \\
\hline 20 & & 8325 & & & & & 99650 & 442,59 & 369,07 & & $-1,78$ & 3,17 & & \\
\hline \multicolumn{9}{|c|}{ Jumlah } & 7417,09 & & & 22992,30 & & \\
\hline
\end{tabular}

$\mathrm{S}=\sqrt{\frac{(\sigma b-\sigma b m)^{2}}{n-1}} \quad \sigma b k=\sigma b m-1,64 \mathrm{~S}$

Tabel Hasil Pemeriksaan Kuat Tekan Beton Variasi Sampel Tidak Mendapat Pengaruh Cuaca (Panas/Hujan) Secara Langsung (180 hari)

\begin{tabular}{|c|c|c|c|c|c|c|c|c|c|c|c|c|c|c|}
\hline \multirow[b]{2}{*}{ No. } & \multirow{2}{*}{$\begin{array}{l}\text { Umur } \\
\text { Hari }\end{array}$} & \multirow{2}{*}{$\begin{array}{c}\text { Berat } \\
\text { (gr) }\end{array}$} & \multirow{2}{*}{$\begin{array}{c}\text { Benda } \\
\text { UJi }\end{array}$} & \multirow[b]{2}{*}{ Konversi } & \multirow{2}{*}{$\begin{array}{c}\text { Slump } \\
(\mathrm{cm})\end{array}$} & \multirow{2}{*}{$\begin{array}{c}\text { Ukuran } \\
\left(\mathrm{cm}^{2}\right)\end{array}$} & \multirow{2}{*}{$\begin{array}{c}\text { Beban } \\
\text { Max } \\
(\mathrm{kg})\end{array}$} & \multicolumn{2}{|c|}{ Tekanan $\left(\mathrm{kg} / \mathrm{cm}^{2}\right)$} & \multirow{2}{*}{$\begin{array}{c}\text { Rata- } \\
\text { rata } \\
\text { obm }\end{array}$} & \multirow{2}{*}{$\begin{array}{l}\Sigma b- \\
\sigma b m\end{array}$} & \multirow{2}{*}{$\begin{array}{c}(\sigma b- \\
\sigma b m)^{2}\end{array}$} & \multirow{2}{*}{$\begin{array}{c}\text { Standar } \\
\text { Deviasi } \\
(\mathbf{S})\end{array}$} & \multirow{2}{*}{$\begin{array}{c}\sigma b k \\
\left(\mathrm{~kg} / \mathrm{cm}^{2}\right)\end{array}$} \\
\hline & & & & & & & & Hari & $\begin{array}{c}90 \text { hari } \\
\text { ob }\end{array}$ & & & & & \\
\hline 1 & 2 & 3 & 4 & 5 & 6 & 7 & 8 & 9 & 10 & 11 & 12 & 13 & 14 & 15 \\
\hline 1 & \multirow{20}{*}{180} & 8008 & \multirow{20}{*}{ Kubus } & \multirow{20}{*}{1,20} & \multirow{20}{*}{8} & \multirow{20}{*}{225} & 84700 & 376,44 & 313,70 & \multirow{20}{*}{359,64} & $-45,94$ & 2110,48 & \multirow{20}{*}{17,93} & \multirow{20}{*}{330,23} \\
\hline 2 & & 8000 & & & & & 90050 & 400,22 & 333,52 & & $-26,12$ & 682,25 & & \\
\hline 3 & & 7940 & & & & & 98300 & 436,89 & 364,07 & & 4,43 & 19,62 & & \\
\hline 4 & & 8220 & & & & & 96550 & 429,11 & 357,59 & & $-2,05$ & 4,20 & & \\
\hline 5 & & 8267 & & & & & 99180 & 440,80 & 367,33 & & 7,69 & 59,14 & & \\
\hline 6 & & 8195 & & & & & 97350 & 432,67 & 360,56 & & 0,92 & 0,85 & & \\
\hline 7 & & 8198 & & & & & 101000 & 448,89 & 374,07 & & 14,43 & 208,22 & & \\
\hline 9 & & 8173 & & & & & 97500 & 433,33 & 361,11 & & 1,47 & 2,16 & & \\
\hline 9 & & 8040 & & & & & 99750 & 443,33 & 369,44 & & 9,80 & 96,04 & & \\
\hline 10 & & 8099 & & & & & 100500 & 446,67 & 372,22 & & 12,5 & 158,26 & & \\
\hline 11 & & 8242 & & & & & 87550 & 389,11 & 324,26 & & 35,38 & 1251,74 & & \\
\hline 12 & & 8049 & & & & & 99250 & 441,11 & 367,59 & & 7,95 & 63,20 & & \\
\hline 13 & & 8170 & & & & & 99700 & 443,11 & 369,26 & & 9,62 & 92,54 & & \\
\hline 14 & & 8330 & & & & & 99800 & 443,56 & 369,63 & & 9,99 & 99,80 & & \\
\hline 15 & & 8100 & & & & & 101100 & 449,33 & 374,44 & & 14,80 & 219,04 & & \\
\hline 16 & & 8070 & & & & & 101150 & 449,56 & 374,63 & & 14,99 & 224,70 & & \\
\hline 17 & & 8160 & & & & & 9850 & 439,78 & 366,48 & & 6,84 & 46,79 & & \\
\hline IS & & 8414 & & & & & 99550 & 442,44 & 368,70 & & 9,06 & 82,08 & & \\
\hline 19 & & 8132 & & & & & 90510 & 402,27 & 335,22 & & $-24,42$ & 596,34 & & \\
\hline 20 & & 8128 & & & & & 99650 & 442,89 & 369,07 & & 9,43 & 88,92 & & \\
\hline \multicolumn{9}{|c|}{ Jumlah } & 7192,89 & & & 610637 & & \\
\hline
\end{tabular}

$\mathrm{S}=\sqrt{\frac{(\sigma b-\sigma b m)^{2}}{n-1}} \quad \sigma b k=\sigma b m-1,64 \mathrm{~S}$ 
JURNAL KACAPURI

JURNAL KEILMUAN TEKNIK SIPIL

Volume 3 Nomor 2 Edisi Desember 2020

Tabel Hasil Pemeriksaan Kuat Tekan Beton Variasi Sampel Tidak Mendapat Pengaruh Cuaca (Panas/Hujan) Secara Langsung (360 hari)

\begin{tabular}{|c|c|c|c|c|c|c|c|c|c|c|c|c|c|c|}
\hline \multirow[b]{2}{*}{ No. } & \multirow[b]{2}{*}{$\begin{array}{l}\text { Umur } \\
\text { Hari }\end{array}$} & \multirow[b]{2}{*}{$\begin{array}{c}\text { Berat } \\
\text { (gr) }\end{array}$} & \multirow[b]{2}{*}{$\begin{array}{c}\text { Benda } \\
\text { UJi }\end{array}$} & \multirow[b]{2}{*}{ Konversi } & \multirow[b]{2}{*}{$\underset{(\mathrm{cm})}{\text { Slump }}$} & \multirow{2}{*}{$\begin{array}{c}\text { Ukuran } \\
\left(\mathrm{cm}^{2}\right)\end{array}$} & \multirow{2}{*}{\begin{tabular}{|c|} 
Beban \\
Max \\
$(\mathrm{kg})$
\end{tabular}} & \multicolumn{2}{|c|}{ Tekanan $\left(\mathrm{kg} / \mathrm{cm}^{2}\right)$} & \multirow{2}{*}{$\begin{array}{l}\text { Rata- } \\
\text { rata } \\
\text { obm }\end{array}$} & \multirow[b]{2}{*}{$\begin{array}{l}\Sigma \mathbf{b}- \\
\sigma \mathbf{b m}\end{array}$} & \multirow[b]{2}{*}{$\begin{array}{c}(\sigma b- \\
\sigma b m)^{2}\end{array}$} & \multirow{2}{*}{$\begin{array}{c}\text { Standar } \\
\text { Deviasi } \\
\text { (S) }\end{array}$} & \multirow{2}{*}{$\begin{array}{c}\sigma b k \\
\left(\mathrm{~kg} / \mathrm{cm}^{2}\right)\end{array}$} \\
\hline & & & & & & & & Hari & $\begin{array}{c}90 \text { hari } \\
\sigma b\end{array}$ & & & & & \\
\hline 1 & 2 & 3 & 4 & 5 & 6 & 7 & 8 & 9 & 10 & 11 & 12 & 13 & 14 & 15 \\
\hline $\begin{array}{c}1 \\
2 \\
3 \\
4 \\
5 \\
6 \\
7 \\
9 \\
9 \\
10 \\
11 \\
12 \\
13 \\
14 \\
15 \\
16 \\
17 \\
\text { IS } \\
19 \\
20\end{array}$ & 360 & $\begin{array}{l}7944 \\
7800 \\
7690 \\
7700 \\
7719 \\
7770 \\
7917 \\
7830 \\
7748 \\
7865 \\
7860 \\
7820 \\
7750 \\
7760 \\
7948 \\
7750 \\
7814 \\
7800 \\
7990 \\
7880\end{array}$ & Kubus & 1,20 & 8 & 225 & \begin{tabular}{|c|}
103090 \\
101410 \\
$100 S 40$ \\
104120 \\
$9 \mathrm{~S} 070$ \\
98980 \\
100830 \\
101850 \\
101520 \\
104020 \\
93880 \\
97430 \\
101540 \\
104230 \\
101420 \\
99370 \\
98720 \\
$95 \mathrm{~S} 90$ \\
101360 \\
99440
\end{tabular} & \begin{tabular}{|l}
458.18 \\
450,71 \\
448.18 \\
462.76 \\
435,87 \\
439,91 \\
448,13 \\
452,67 \\
451.20 \\
462,31 \\
417.24 \\
433,02 \\
451.29 \\
463.24 \\
450.76 \\
441,64 \\
438.76 \\
426.18 \\
450,49 \\
441.96
\end{tabular} & \begin{tabular}{|l|}
366.54 \\
360,57 \\
358.54 \\
370,20 \\
348,69 \\
351.93 \\
358,51 \\
362,13 \\
36096 \\
369,85 \\
333,80 \\
346,12 \\
361,03 \\
370.60 \\
360.60 \\
353,32 \\
351,00 \\
340.94 \\
360,39 \\
353,56
\end{tabular} & 356,98 & $\begin{array}{c}8,57 \\
2,70 \\
0,67 \\
12,33 \\
-9,18 \\
-5,94 \\
0,64 \\
4,26 \\
3,09 \\
11,98 \\
-23,18 \\
-10,56 \\
3,16 \\
12,73 \\
2.73 \\
-4,55 \\
-6,87 \\
-16,93 \\
2,52 \\
-4,31\end{array}$ & \begin{tabular}{|c|}
75,17 \\
7,29 \\
0,45 \\
152,03 \\
84.27 \\
35,28 \\
0,41 \\
18,15 \\
9,55 \\
143.52 \\
537,31 \\
111,52 \\
9,99 \\
162,05 \\
7,45 \\
20,70 \\
47,20 \\
286,62 \\
6.35 \\
18,58
\end{tabular} & 9,55 & 3412,32 \\
\hline \multicolumn{9}{|c|}{ Jumlah } & \begin{tabular}{|l|}
7139,58 \\
\end{tabular} & & & 1733,89 & & \\
\hline
\end{tabular}

$\mathrm{S}=\sqrt{\frac{(\sigma b-\sigma b m)^{2}}{n-1}} \quad \sigma b k=\sigma b m-1,64 \mathrm{~S}$

\section{Perhitungan Kekuatan Beton K-225}

Dimana:

$$
\begin{aligned}
\sigma^{\prime} \mathrm{bm} & =\frac{\sum_{1}^{n} \sigma / \mathrm{b}}{n} \\
\sigma^{\prime} \mathrm{bk}^{\mathrm{n}} & =\sigma^{\prime} \mathrm{bm}^{\mathrm{n}}-1,64 \mathrm{Sn}>\sigma^{\prime} \mathrm{bk}^{\mathrm{r}}
\end{aligned}
$$

$\sigma^{\prime} \mathrm{bk}^{\mathrm{n}}=$ Kekuatan tekan beton karakteristik $\left(\mathrm{kg} / \mathrm{cm}^{2}\right)$

$\sigma^{\prime} \mathrm{bm}^{\mathrm{n}}=$ Kekua tan tekan beton rata-rata $\left(\mathrm{kg} / \mathrm{cm}^{2}\right)$

$\sigma^{\prime} b^{r}=$ Kekuatan tekan beton rencana $\left(\mathrm{kg} / \mathrm{cm}^{2}\right)$

$\mathrm{Sn}=$ Standar deviasi

1. Beton yang tidak mendapat pengaruh cuaca (Panas/Hujan) secara langsung (90 hari)

$$
\begin{aligned}
\sigma^{\prime} \mathrm{bm} & =\frac{\sum_{1}^{n} \sigma \prime \mathrm{b}}{n}=\frac{7417,09}{20} \\
& =370,85 \mathrm{~kg} / \mathrm{cm}^{2} \\
\sigma^{\prime} \mathrm{bk} & =\sigma^{\prime} \mathrm{bm}-1,64 . \mathrm{S}>\sigma^{\prime} \mathrm{bk}^{\mathrm{r}}
\end{aligned}
$$

Dimana:

$\mathrm{S}=11,00$

$\sigma^{\prime} \mathrm{bk}=352,81 \mathrm{~kg} / \mathrm{cm}^{2}>225 \mathrm{~kg} / \mathrm{cm}^{2} \rightarrow$ memenuhi

2. Beton yang mendapat pengaruh cuaca (panas/hujan) secara langsung (90 hari)

$$
\begin{aligned}
\sigma^{\prime} \mathrm{bm} & =\frac{\sum_{1}^{n} \sigma \prime \mathrm{b}}{n}=\frac{7192,89}{20} \\
& =369,64 \mathrm{~kg} / \mathrm{cm}^{2} \\
\sigma^{\prime} \mathrm{bk} & =\sigma^{\prime} \mathrm{bm}-1,64 . \mathrm{S}>\sigma^{\prime} \mathrm{bk}^{\mathrm{r}}
\end{aligned}
$$

Dimana:

$\mathrm{S}=17,93$

$\sigma^{\prime} \mathrm{bk}=330,23 \mathrm{~kg} / \mathrm{cm}^{2}>225 \mathrm{~kg} / \mathrm{cm}^{2} \rightarrow$ memenuhi 
3. Beton yang mendapat pengaruh cuaca (panas/hujan) secara langsung (180 hari)

$$
\begin{aligned}
\sigma^{\prime} \mathrm{bm} & =\frac{\sum_{1}^{n} \sigma / \mathrm{b}}{n}=\frac{7139,58}{20} \\
& =356,98 \mathrm{~kg} / \mathrm{cm}^{2} \\
\sigma^{\prime} \mathrm{bk} & =\sigma^{\prime} \mathrm{bm}-1,64 . \mathrm{S}>\sigma^{\prime} \mathrm{bk}^{\mathrm{r}}
\end{aligned}
$$

Dimana:

$$
\mathrm{S} \quad=9,55
$$

$\sigma^{\prime} \mathrm{bk}=341,32 \mathrm{~kg} / \mathrm{cm}^{2}>225 \mathrm{~kg} / \mathrm{cm}^{2} \rightarrow$ memenuhi

\section{Diagram Tegangan Beton Karakteristik (Tbk)}

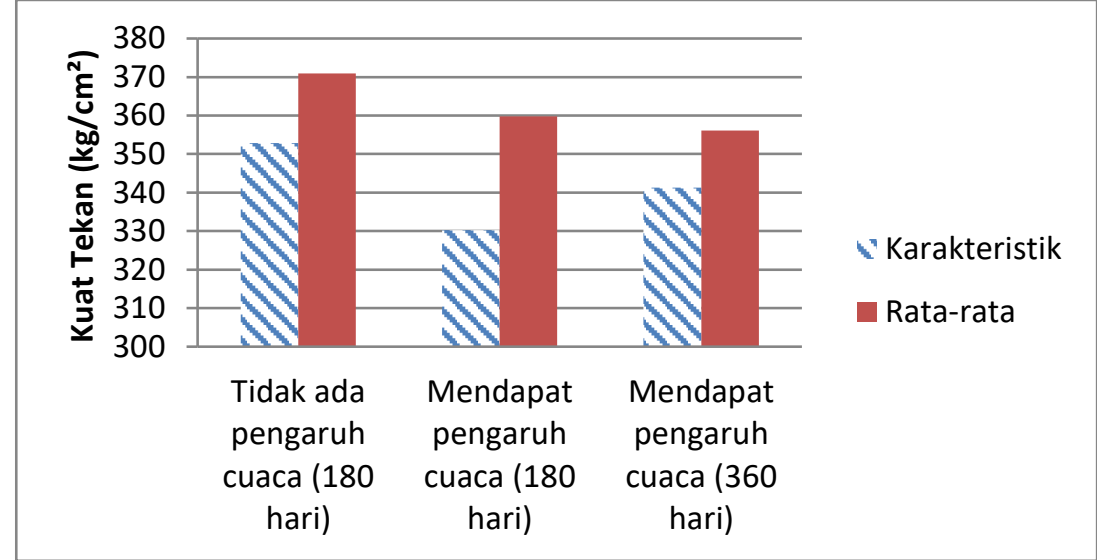

Dari data perhitungan tegangan karakteristik, didapat pengaruh cuaca (panas/hujan) secara langsung terhadap mutu beton K-225 terjadi penurunan

\begin{tabular}{|c|c|c|c|c|}
\hline $\begin{array}{c}\text { Kelompok Variasi } \\
\text { Sampel }\end{array}$ & $\begin{array}{c}\text { Standar } \\
\text { deviasi }\end{array}$ & $\begin{array}{c}\text { Hari } \\
(\%)\end{array}$ & $\begin{array}{c}\text { Tegangan } \\
\text { Karakteristik Beton } \\
\left(\mathbf{k g} / \mathrm{cm}^{2}\right)\end{array}$ & $\begin{array}{c}\text { Penurunan } \\
\text { Tegangan (\%) }\end{array}$ \\
\hline $\begin{array}{l}\text { I. Tidak mendapat pengaruh cuaca } \\
\text { secara langsung (180 hari) }\end{array}$ & 11,00 & 100 & 352,81 & 0 \\
\hline $\begin{array}{l}\text { II. Mendapat pengaruh cuaca secara } \\
\text { langsung (180 hari) }\end{array}$ & 17,93 & 100 & 330,23 & 6,84 \\
\hline $\begin{array}{l}\text { III. Mendapat pengaruh cuaca secara } \\
\text { langsung ( } 360 \text { hari) }\end{array}$ & 9,55 & 100 & 341,32 & 3,37 \\
\hline
\end{tabular}
tegangan karakteristiknya dibandingkan dengan yang tidak mendapat pengaruh cuaca secara langsung, seperti pada perhitungan dan Tabel berikut ini:

Tabel Prosentase Perubahan Tegangan Karakteristik Beton

Sumber: Hasil Perhitungan

Perhitungan:

$$
\begin{aligned}
\text { Penurunan tegangan } & =\frac{\sigma^{\prime} b k I-\sigma^{\prime} b k I I}{\sigma^{\prime} b k I I} \times 100 \% \\
& =\frac{352.81-330,23}{330,23} \times 100 \% \\
& =6,84 \%
\end{aligned}
$$

$$
\begin{aligned}
\text { Penurunan tegangan } & =\frac{\sigma^{\prime} b k I-\sigma^{\prime} b k I I}{\sigma^{\prime} b k I I} \times 100 \% \\
& =\frac{352.81-341,32}{341,32} \times 100 \% \\
& =3,37 \%
\end{aligned}
$$


JURNAL KACAPURI

JURNAL KEILMUAN TEKNIK SIPIL

Volume 3 Nomor 2 Edisi Desember 2020

\section{Analisis Pengujian Hipotesis}

Dari perhitungan diatas dapat dilakukan pengujian hipotesa terhadap kekuatan beton K-225. Digunakan pengujian hipotesis dengan menguji kesamaan dua ratarata dengan uji satu pihak, pasangan hipotesis $\mathrm{H}_{0}$ dan $\mathrm{H}_{1}$ yang akan diuji adalah:

$\mathrm{H}_{0}: \mu 1=\mu 2$, diduga indeks satu sama dengan indeks dua

$\mathrm{H}_{1}: \mu 1>\mu 2$, indeks satu lebih besar dari pada indeks dua Statistik yang digunakan adalah statistik " $\mathrm{t}$ "

$$
\mathrm{t}=\frac{X_{1}-X_{2}}{S \sqrt{\left(\frac{1}{n_{1}}\right)+\left(\frac{1}{n_{2}}\right)}} \text { dengan: } \mathrm{S}^{2}=\frac{\left(n_{1}-1\right) \cdot S_{1}^{2}+\left(n_{2}-1\right) \cdot S_{2}^{2}}{n_{1}+n_{2}-2}
$$

Tabel Data Kekuatan Beton 180 Hari

\begin{tabular}{|c|c|c|c|}
\hline Kelompok Variasi Sampel & $\begin{array}{c}\text { Tidak Mendapat } \\
\text { Pengaruh Cuaca Secara } \\
\text { Langsung }\end{array}$ & $\begin{array}{l}\text { Mendapat Pengaruh } \\
\text { Cuaca Secara Langsung }\end{array}$ & Keterangan \\
\hline 1. & 356,37 & 313,70 & \\
\hline 2. & 371,85 & 333,52 & \\
\hline 3. & 381,11 & 364,07 & \\
\hline 4. & 379,44 & 357,59 & \\
\hline 5. & 370,74 & 367,33 & \\
\hline 6. & 384,44 & 360,56 & \\
\hline 7. & 379,26 & 374,07 & \\
\hline 8. & 386,85 & 361,11 & \\
\hline 9. & 368,33 & 369,44 & \\
\hline 10. & 353,89 & 372,22 & \\
\hline 11. & 371,85 & 324,26 & \\
\hline 12. & 376,30 & 367,59 & \\
\hline 13. & 357,59 & 369,26 & \\
\hline 14. & 347,04 & 369,63 & \\
\hline 15. & 357,59 & 374,44 & \\
\hline 16. & 373,52 & 374,63 & \\
\hline 17. & 374,44 & 366,48 & \\
\hline 18. & 376,67 & 368,70 & \\
\hline 19. & 380,74 & 335,22 & \\
\hline 20. & 369,07 & 369,07 & \\
\hline Jumlah & 7417,09 & 7192,89 & 14609,98 \\
\hline Pengamatan & 20 & 20 & 40 \\
\hline Rata-rata & 370,86 & 359,65 & 365,25 \\
\hline
\end{tabular}

$(\alpha)$ Level Signifikan : 0,05

$$
\begin{aligned}
& \mathrm{n}_{1}: 20 \\
& \mathrm{X}_{1}=370,86 \\
& \mathrm{n}_{2}: 20 \quad \mathrm{X}_{2}=359,65 \\
& \mathrm{Dk}=\left(\mathrm{n}_{1}+\mathrm{n}_{2}-2\right) \\
& =(20+20-2) \\
& =38
\end{aligned}
$$

$\mathrm{S}_{1}=11,00$

$\mathrm{S}_{2}=17,93$

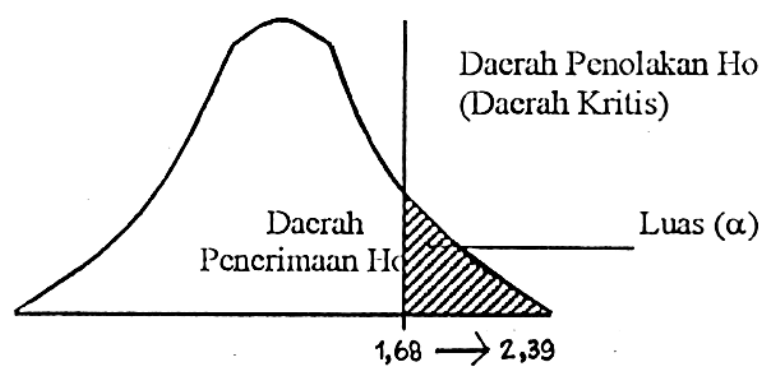

Sketsa Distribusi 
JURNAL KACAPURI

JURNAL KEILMUAN TEKNIK SIPIL

Volume 3 Nomor 2 Edisi Desember 2020

Tabel Data Kekuatan Beton 180 hari dan 360 hari

\begin{tabular}{|c|c|c|c|}
\hline Kelompok Variasi Sampel & $\begin{array}{c}\text { Tidak Mendapat } \\
\text { Pengaruh Cuaca Secara } \\
\text { Langsung }\end{array}$ & $\begin{array}{l}\text { Mendapat Pengaruh } \\
\text { Cuaca Secara Langsung }\end{array}$ & Keterangan \\
\hline 1. & 356,37 & 366,54 & \\
\hline 2. & 371,85 & 360,57 & \\
\hline 3. & 381,11 & 358,54 & \\
\hline 4. & 379,44 & 370,20 & \\
\hline 5. & 370,74 & 348,59 & \\
\hline 6. & 384,44 & 351,93 & \\
\hline 7. & 379,26 & 358,51 & \\
\hline 8. & 386,85 & 362,13 & \\
\hline 9. & 368,33 & 360,96 & \\
\hline 10. & 353,89 & 369,85 & \\
\hline 11. & 371,85 & 333,80 & \\
\hline 12. & 376,30 & 346,42 & \\
\hline 13. & 357,59 & 361,03 & \\
\hline 14. & 347,04 & 370,60 & \\
\hline 15. & 357,59 & 360,60 & \\
\hline 16. & 373,52 & 353,32 & \\
\hline 17. & 374,44 & 351,00 & \\
\hline 18. & 376,67 & 340,94 & \\
\hline 19. & 380,74 & 360,39 & \\
\hline 20. & 369,07 & 353,56 & \\
\hline Jumlah & 7417,09 & 7139,58 & 14556,67 \\
\hline Pengamatan & 20 & 20 & 40 \\
\hline Rata-rata & 370,86 & 356,98 & 363,92 \\
\hline
\end{tabular}

$(\alpha)$ Level Signifikan : 0,05

$$
\begin{aligned}
\mathrm{n}_{1}: & 20 \quad \mathrm{X}_{1}=370,86 \\
\mathrm{n}_{2}: & 20 \quad \mathrm{X}_{2}=356,98 \\
\mathrm{Dk} & =\left(\mathrm{n}_{1}+\mathrm{n}_{2}-2\right) \\
& =(20+20-2) \\
& =38 \\
\mathrm{~S}_{1} & =11,00 \\
\mathrm{~S}_{2} & =9,553
\end{aligned}
$$

Daerah Penolakan Ho (Daerah Kritis)

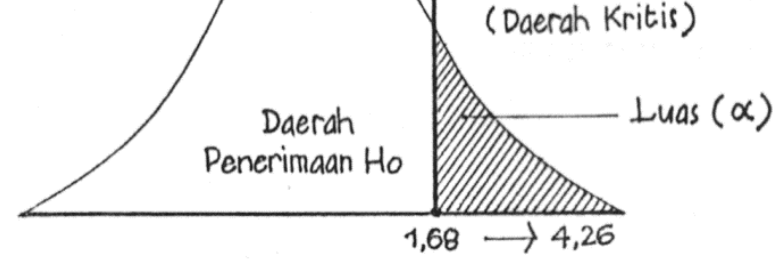

Sketsa Distribusi

\section{Kesimpulan}

\section{PENUTUP}

1. Dari hasil pengujian yang telah dilakukan di laboratorium terhadap beton dengan benda uji berbentuk kubus yang dirancang dengan metode DOE/Department Of Environmental (SK SNI -T-15-1990-03), maka dapat dilihat bahwa metode tersebut memberikan hasil yang sesuai dengan mutu beton rencana yaitu:

- Dari variasi perlakuan sampel pertama didapat

$\sigma^{\prime} \mathrm{bk}=352,81 \mathrm{~kg} / \mathrm{cm}^{2}>225 \mathrm{~kg} / \mathrm{cm}^{2}$

- Dari variasi perlakuan sampel kedua didapat $\sigma^{\prime}$ bk $=330,23 \mathrm{~kg} / \mathrm{cm}^{2}>225 \mathrm{~kg} / \mathrm{cm}^{2}$ 
- Dari variasi perlakuan sampel ketiga didapat

$\sigma^{\prime} \mathrm{bk}=341,32 \mathrm{~kg} / \mathrm{cm}^{2}>225 \mathrm{~kg} / \mathrm{cm}^{2}$

2. Melihat perilaku dari kuat tekan beton yang ditunjukkan masing-masing variasi perlakuan sampel yang digunakan pada penelitian, ternyata beton yang mendapat pengaruh cuaca (panas dan hujan) secara langsung mengalami penurunan tegangan sebesar $6,84 \%$ dan $3,37 \%$ dari beton yang tidak mendapat pengaruh cuaca (panas dan hujan) secara langsung.

3. Pada beton yang mendapat pengaruh cuaca (panas dan hujan) secara langsung selama 360 hari, ternyata penurunan tegangannya lebih kecil dibanding dengan yang mendapat perlakuan yang sama, tetapi dengan waktu 180 hari.

\section{Saran- saran}

ini dapat memberikan manfaat berupa informasi dari kenyataan yang didapat namun juga tidak terlepas dari berbagai kekurangan, peneliti merasa perlu untuk memberikan saran-saran guna lebih sempurnanya penelitian.

- Dalam melakukan penelitian di laboratorium diperlukan ketelitian dan akurasi alat yang baik.

- Mempergunakan material untuk benda uji yang benar-benar dalam kondisi asli dari asalnya.

- Diusahakan pada penelitian yang selanjutnya, sebaiknya lebih banyak menggunakan sampel dan variasi waktu yang lebih banyak pula (pada saat musim panas dan pada saat musim hujan).

- Diusahakan menyelidiki pada sampel beton bertulang sebagaimana aslinya.

\section{DAFTAR PUSTAKA}

1. Ali Hanafiah M., 2004. Merencanakan Komposisi Campuran Beton Struktural, Fakultas Teknik Universitas Syiah Kuala Darussalam, Banda Aceh.

2. Lin T. Y. - Burns H., 2008. Design Struktur Beton Prategang, Erlangga Jakarta.

3. Ritonga Abdulrahman, 2007. Statistika Terapan Untuk Penelitian, Erlangga Jakarta

4. Henri Wardana, 2001. Petunjuk Praktikum Beton, Fakultas Teknik Universitas Lambung Mangkurat, Banjarmasin.

5. SK SNI M-62-1990-03. Metode Pembuatan dan Perawatan Benda Uji Beton di Laboratorium, Yayasan LPMB Bandung.

6. SK SNI S-04-1989-F. Spesifikasi, Yayasan LPMB Bandung.

7. SK SNI T-15-1991-03. Tata Cara Pembuatan Rencana Campuran Beton Normal, Yayasan LPMB Bandung.

8. SK SNI T-28-1991-03. Tata Cara Pengadukan dan Pengecoran Beton, Yayasan LPMB Bandung.

9. Subakti Aman, 2003. Teknologi Beton Dalam Praktek 1, TTS.

10. Sudjana, 2002. Metode Statistika, Tarsito Bandung.

11. W. II. Mosley dan Bungey J. H, 2004. Perencanaan Beton Bertulang, Erlangga Jakarta. 